\title{
Sobre Sanín Cano, Maestro
}

Poco después de llegar al París de 1928 oí por primera vez el nombre de Sanín Cano. Lo digo con pena pero sin vergüenza, porque tales lagunas eran y siguen siendo frecuentes en Hispanoamérica. Es en París, en Madrid, en Nueva York donde los hispanoamericanos -mexicanos, colombianos, argentinos...- nos hacemos continentales.

El México de mi adolescencia había recibido un baño de hispanoamericanismo gracias a don José Vasconcelos, que desde el Ministerio de Educación Pública hablaba de Hispanoamérica, había vivido en el Perú y entonces empezaba a recorrerla, mandaba al sur del Suchiate a estudiantes que nos traían noticia de las tierras desconocidas, y traía de ella profesores, escritores, poetas. Estudiante de la Escuela Nacional Preparatoria, respiraba yo hispanoamericanismo de buena ley en buen sitio para respirarlo, en las viejas aulas y en los amplios corredores del viejo Colegio de San Ildefonso, completamente ajeno al mérito de quienes lo creaban. A Vasconcelos lo vi una sola vez - y no precisamente con simpatía-, el día de la huelga de preparatorianos de 1923. A Carlos Pellicer, conterráneo mío que volvía de Colombia, lo oí conversar de sus amigos bogotanos en la antesala del Rector. Fuí alumno, por unas semanas, del nicaragüense Salomón de la Selva y del costarricense Moisés Vincenzi. Oí hablar, vagamente, de Gabriela Mistral. Pero, ingratos como buenos adolescentes, no sabíamos que algo nuevo se nos daba.

El fruto, que es lo que importa, maduraba. En el tercer curso de historia general que nos daba el inolvidable maestro José Luis Ossorio Mondragón y en el que poco se hablaba de Hispanoamérica, yo, por propia iniciativa, inexplicable para casi todos mis compañeros y aun para mí mismo, solicité permiso para escribir un tra- 
bajo de clase sobre Bolívar. Esto era en el año de 1925. Ossorio me dijo, entre bromas y veras, con su típica cortesía: ¿ No naufragará en ese mar proceloso la frágil barquichuela?... Pero cuando lo leyó me pidió que lo leyera en clase. Luego escribí y leí otro sobre José Martí. La información era breve, pero el entusiasmo mío y de los demás estudiantes se hizo grande. Sobre Bolívar la base era Rufino Blanco-Fombona, cuyas ediciones madrileñas pasaban por nuestras manos, y sobre Martí el mismo Fombona y la primera biografía de M. Isidro Méndez.

Yo tenía, desde mi infancia costeña, algún interés por Cuba y por Puerto Rico, y por sugestión de don Manuel Mestre Ghigliazza, Director de la Biblioteca Nacional y amigo de mi casa, leía sin parar, con sorpresa de mis compañeros y de mis profesores, los libros de Emilio Bobadilla. Fray Candil me daba, cuando menos, una información general de cuanto ocurría en Europa, y me interesaba en los escritores hispanoamericanos con quienes convivía o peleaba en Francia y España. No quiere esto decir que yo era el que menos ignoraba de Hispanoamérica. Habría que ver la experiencia personal de otros muchachos de mi grupo, que recordarán la suya tanto como yo recuerdo la mía. Pero, sin duda, gracias al aire creado por Vasconcelos y por la casual lectura de Bobadilla, fuí uno de los pocos que a los dieciocho años empezaron a mirar hacia las Antillas y hacia el sur.

La mención de Fray Candil viene muy a cuento porque un día de 1928, en París, cayó en mis manos un librito muy modestamente impreso y casi desencuadernado, editado en Bogotá: Indagaciones $e$ imágenes, por B. Sanín Cano. Fué a parar, no sé cómo, al hotelito estudiantil de la Rue Cujas, del Barrio Latino, donde yo vivía. ¿Fué comprado en la Librairie Espagnole de la Rue Gay-Lussac, que tanto frecuentábamos los hispanoamericanos de París, o algún colombiano lo llevó desde su tierra? Lo que recuerdo claramente es que lo abrí en la página 127 -tengo, naturalmente, otro ejemplar a la vista- y encontré el nombre de Emilio Bobadilla como cabeza de capítulo. Leí sus ocho páginas con avidez y nació mi lazo de afecto y de admiración con Sanín Cano. Me leí todo el libro y a cuanto hispanoamericano o español encontrabá le preguntaba yo por él, por quién era, dónde estaba, qué hacía. $Y$ es que Sanín Cano me había vuelto el alma al cuerpo: casi nadie había leído ni leía 
"a mi Fray Candil" - "tu Fray Candil", me decía siempre, con su punta de ironía, un escritor mexicano a quien frecuentaba en Parísy, sin excepción, todos lo consideraban de poco valor o, cuando menos, cosa pasada y liquidada. Ellos no tenían razón, ni tampoco la tenía yo, pegado con una simple pasión de adolescente al parisismo y al "cientificismo" de Bobadilla, no siempre del mejor gusto, y a su individualismo excesivo y amargo.

En prosa serena, diáfana, nítida, Sanín Cano me hablaba allí del hombre - al que había conocido bien, recordaba su simpatía y su gracia de conversador, la condescendencia personal que lo adornaba en contraste a sus furias y crueldades de crítico, y marcaba sus limitaciones. Me daba el pro que me urgía para autorizar mi adhesión fraycandilesca, pero, con su claro juicio, me apartaba de mi ingenuo fanatismo. El artículo que tanta impresión me hizo, está rematado por una certera frase, que hoy podemos nosotros aplicar a Sanín Cano: "Un hado benigno le había condenado a morir joven, después de los sesenta años." Sanín también se conserva joven hoy, a los ochenta y siete.

Después seguí a don Baldomero a través de muchos artículos y de pocos libros; pero, entre éstos, sigue siendo Imágenes $e$ impresiones el que más me gusta. Lo digo ahora que repaso la colección de recortes y los volúmenes que conserva el Instituto Hispánico de la Universidad de Columbia. Es que a la estimación razonada y global se impone siempre el punto de partida vital y humano.

Sus reconocidas tersura y mesura están ya en el artículo sobre "El descubrimiento de América y la higiene". Allí su galana prosa, sus muchas lecturas, su crítica sonriente. En "Cadenas de estuco" está muy presente su fondo revolucionario, un algo londinense y un mucho bogotano, ordenado y enfrenado pero con presagios de que puede desenfrenarse. En "El hombre disminuye" ve, sin ira, "la tendencia fatídica a nivelar y a nivelarse, tomando para eso las posiciones en que está repantigada la medianía", alta preocupación de los más puros modernistas. Allí mismo aparecen sus sedantes impresiones de reporter de guerra, de espectador reflexivo y emocionado de la del año 14, cuando nos cuenta de una barraca hecha teatro en que el público de soldados aliados "rehusaba noblemente el arma del insulto". Su vida y su obra ajenas al exceso hallan esperanza en aquel paréntesis elocuente. En sus críticas sobre Brandes -a quien guarda una fidelidad permanente-, Galsworthy, Fray Luis 
y Marinetti sentimos y envidiamos su vasto conocimiento de todas las literaturas.

Luego abrimos Divagaciones filológicas y apólogos literarios y nos vamos encontrando con su respuesta a don Juan Valera -el ilustre español que es un precursor en haber querido y en parte logrado conocer las letras hispanoamericanas, no sin caidas de mal humor imperial- escrita en el mismo tono pero con más acopio de datos que el gran andaluz, quien en esa mala ocasión llamó a los hispanoamericanos "arrendajos serviles de los más disparatados extranjeros". Allí colecciona la buena doctrina lingüística que años después refrendan maestros de una España y de una América más cercanas, más sensatas y en camino de la justa reunión, y que tiene como antecedente los pilares americanos que se llaman Bello y Cuervo. Creo que es uno de los primeros que dice que hay que establecer "no cómo se debe hablar, sino cómo se habla". "Interesa más conocer la historia de la lengua - precisa-que todo ese formulario de reglas." "Las academias nos han querido hacer olvidar que el idioma es creación del pueblo." El sabio antiacadémico funda sus avanzados puntos de vista en el conocimiento de muchas lenguas europeas, y de las clásicas.

Hallazgos así hallaremos si seguimos revisando las Divagaciones, sus Ensayos editados en Bogotá en 1942, sus Letras colombianas de reciente aparición en México, que son ahora los libros que tenemos al alcance de la mano. El lector atento recoge aquí, nada más, sus anotaciones marginales: maestro de buena prosa, de ecuanimidad, con "la condescendencia y el buen humor de la verdadera sabiduría" —otra frase suya, de la que ha hecho norte y logro, que enderezamos hacia él-, de responsabilidad literaria, de divulgación útil y honesta; buen disociador de las ideas de los hombres y las culturas de su tiempo, que sin pasión expone la realidad del mundo que vive: "el mundo se está haciendo socialista a la vista de todos", decía a principios del siglo; periodista afilosofado - lo que Montalvo, tan valioso pero tan poco afilosofado, pedía y recomendaba; hombre de primera fila que empeñosamente busca la discreción de la segunda; sucesor de Bello en Londres - no hay que olvidar su oficio de maestro, también ejercido allí, y sus amistades literarias en toda Europa; ejemplo y guía, según Guillermo Valencia; representante de José Asunción Silva en la tierra; estudioso y divulgador de los más altos ingenios 
europeos e hispanoamericanos. ¿ Faltan méritos y nombres para darle permanencia literaria en el mundo de habla española?

No faltan; pero recordemos también su vida de maestro, de funcionario, de diplomático, de maestro que estudia —rara avis, como Germán Arciniegas ha recordado en artículo reciente- y en línea ascendente y recta que va desde sus días de profesor de Titiribí hasta su robusta ancianidad universal.

El homenaje que se le tributa contiene el agradecimiento de tres generaciones que ven en él otro maestro de América.

ANDrÉs IdUARTe, Columbia University, Nueva York. 
